The International Journal of Children's Rights, 13: 433-461, 2005.

\title{
The Principle of Non-Discrimination in the Convention on the Rights of the Child
}

\author{
SAMANTHA BESSON* \\ Professor of Public International and European Law, University of Fribourg
}

\section{Introduction}

Children are discriminated against all the time; little girls are not treated like little boys, disabled children are not treated like non-disabled ones (Lansdown, 2001), rural children do not get the same opportunities as those living in the cities, migrant children do not benefit from the same rights as national children (Breen, 2003), etc.' For all sorts of reasons, however, children are even more vulnerable than adults to discrimination based on gender, religion, race, as well as any other suspect classification. Whereas for a long time this did not attract much attention, things started to change in the 1980s. When the 1989 Convention on the Rights of the Child (CRC) was adopted to protect children's rights in general, the principle of anti-discrimination was wellplaced among the guaranteed rights of the child in art. 2 of the Convention. The question one may ask, however, is the following: in retrospect, what is it that makes child discrimination special when compared to other kinds of discrimination and how does the CRC protect them better against discrimination than other existing international guarantees of the general principle of non-discrimination?

To reply to this question, it is important to look into the principle of nondiscrimination in general and its guarantees in major international human rights instruments. It is only by replacing the principle in its general context that one is able to grasp the full measure of the progress made with art. 2 CRC, but also of some of its current limitations. ${ }^{2}$ True, the principle of nondiscrimination is a traditional topic that was addressed extensively at the time of the adoption of the CRC (Hitch, 1989; Alston, 1992; Van Bueren, 1995, Ch. 2; LeBlanc, 1995; Detrick, 1999, Art. 2; Muscroft, 2000, Part I; Hodgkin/Newell, 2002, art. 2). However, the fact that most of the existing literature about art. 2 CRC dates back a few years justifies taking a fresh look at the status of the protection of children against discrimination in the Convention. In what follows, I will start by presenting some definitions and distinctions pertaining to the concept of non-discrimination (1.), before presenting, in a second section, the principle of non-discrimination in general as 
guaranteed in major international human rights instruments (2.). Finally, a third section will address the principle of non-discrimination in the CRC (3.).

\section{Definitions and distinctions of the principle of non-discrimination}

Equality is a deep-rooted principle in human morality. Unsurprisingly, therefore, the principle has quickly been recognized legally as one of the fundamental principles of modern democracies. It occupies pride of place in most written constitutions and numerous countries now have anti-discrimination legislation whether against all forms of discrimination or against some specific forms of discrimination only, such as racial or sex discrimination. Whereas traditional international law used not to concern itself with discrimination, except in relation to sovereignty, the Second World War triggered an unprecedented concern for human rights protection and led to guaranteeing them for all without discrimination. From the 1950s onwards, conventional guarantees of the non-discrimination principle multiplied. The principle of non-discrimination is now one of the most frequently protected norms of international human rights law (Kewenig, 1972; Vierdag, 1973; Tomuschat, 1981; McKean, 1983; Dinstein, 1985; Bayefsky, 1990; Partsch, 1993; Ramcharan, 1983, pp. 247-250; Brownlie, 2003, pp. 578-580).

Despite its widespread guarantees and general recognition, the exact content and scope of the principle of non-discrimination remain largely contested. As Judge Tanaka noted in the West Africa Case, 'although the existence of this principle [of non-discrimination] is universally recognized [...], its precise content is not very clear' ${ }^{3}$ It is important therefore to start our discussion of the principle of non-discrimination with a few definitions (a.) and distinctions (b.).

\section{a. Some definitions}

Although non-discrimination is a dominant and recurring theme of international human rights law, the principle is never to be found in a single and uniform fashion in the different sources of international law. Nor do most of its guarantees explain what its content is in a holistic way (Bayefsky, 1990, p. 34). If the ideal of non-discrimination has obvious appeal, its content is not so clearly apparent and this probably for reasons of consensus-reaching. ${ }^{4}$

Before turning to potential definitions of the principle, it is worth pausing briefly on two dimensions of its equivocal meaning. To start with, the principle of non-discrimination is often identified with that of equality (Bayefsky, 1990, p. 1). This is because equality and non-discrimination are positive and negative statements of the same principle. ${ }^{5}$ One is treated equally when one 
is not discriminated against and one is discriminated against when one is not treated equally. In what follows, therefore, I will refer to equality to capture the positive dimension of equality, with all the measures of promotion of equality in practice, whereas non-discrimination will be used to refer to the negative absence of discrimination (McKean, 1983, p. 285). Furthermore, even when defined in close connexion with the principle of non-discrimination, the principle of equality has been heavily criticized for being nothing more than an empty idea (Westen, 1982). All it says is that people should benefit equally from other rights they have. It adds nothing, in other words, to the existence of those rights which pre-exists the equality concern. This critique only cuts some ice, however, if one regards equality as a right or principle like all others. This need not be the case. Equality should much rather be seen as a qualifying principle which pertains to the way in which other rights and principles are applied and the way in which people are therefore shown due respect as autonomous human beings. Understood in this adverbial way, equality need no longer be compared to other rights and principles and cannot therefore be deemed empty (Raz, 1986, p. 230).

Although most instruments do not define what they mean by 'discrimination', the most commonly quoted definition is that of the UN Human Rights Committee established under the UN Covenant on civil and political rights. According to that definition, discrimination should be understood to imply

'any distinction, exclusion, restriction or preference which is based on any ground such as race, colour, sex, language, religion, political or other opinion, national or social origin, property, birth or other status and which has the purpose or effect of nullifying or impairing the recognition, enjoyment or exercise by all persons, on an equal footing, of all rights and freedoms.' 6

One may capture the different elements in this definition in the following working definition: the principle of non-discrimination prohibits treating differently similar situations without an objective justification. There are roughly four elements in this definition (Bayefsky, 1990, pp. 11-24): the differentiation of similar situations (i.), the absence of legitimate ends (ii.), the lack of proportionality of means to ends (iii.) and the use of suspect classifications (iv.).

\section{i. Differentiation of similar situations}

The first constitutive element of a discrimination is the different treatment of similar situations, but also the similar treatment of different situations. One often finds the term 'distinction' used interchangeably with that of discrimination. Of course, what makes situations different or alike is a matter of evaluation of which substantial factual differences should count and of how they should count. This is clearly a very controversial evaluation to perform. It should not, however, be confused with the judgement of discrimination itself which relies on the pre-existence of a similar situation being treated differently. 
The principle of non-discrimination prohibits discrimination as antentional unjustified distinction of similar situations. The latter's aim is to impair the equal enjoyment by all persons of all rights and freedoms. The principle of non-discrimination also prohibits, however, unintentional distinctions which result in effect in a discrimination. This is what follows from most international guarantees of the principle of non-discrimination (McKean, 1983 , p. 287; Bayefsky, 1990, pp. 8-10).

\section{ii. Absence of legitimate ends}

Not all differences in treatment are discriminatory, only those which lack an objective justification. ${ }^{7}$ The existence of such a justification must be assessed in relation to the aim and effects of the measure under consideration, bearing in mind the principles which normally prevail in democratic societies. Such aims may not be unjust or unreasonable, in that they may not be arbitrary, capricious, despotic or in conflict with the essential dignity of humankind.

One kind of ready justification and legitimate purpose of discrimination may be the redress of historical injustice and past discrimination. In these cases, discrimination may have as an aim to ensure material equality, even if this means violating formal equality. This may, for instance, justify discriminating men formally to promote women, even when they are equally qualified, in order to redress past discrimination of women in the labour market.

\section{iii. Lack of proportionality of means to ends}

A difference of treatment must not only pursue a legitimate aim to be a justified distinction. There must also be a reasonable relationship of proportionality between the means employed and the ends sought. There are three conditions for this proportionality test. The means must be apt to attain the aim sought, be necessary means to do so and be the least restrictive means to reach that aim.

\section{iv. Suspect classifications}

One may differentiate similar situations or treat different situations alike for all sorts of reasons. Someone may be discriminated without justification simply because he is bald or too short. To be able to speak of discrimination, however, one needs to identify a 'suspect' classification. Some grounds of discrimination are deemed more suspect than others and call for a more stringent scrutiny on the part of authorities (Bayefsky, 1990, pp. 18-24). The key difference between these classifications and other grounds of discrimination is that very weighty justifications have to be put forward to justify a difference of treatment based on them. This is the case of grounds of discrimination like sex, birth, race, religion, disability, etc.

Suspect classifications are usually listed in non-discrimination clauses, but they can also stem from the case-law of major international human rights 
bodies. These grounds are often mentioned in a non-exhaustive and purely indicative manner. Thus, their list is constantly being expanded, as illustrated by art. 2 of the Convention on the Rights of the Child which expressly protects against discrimination on grounds of disability, whereas this ground was never specifically mentioned before, as we will see.

\section{b. Some distinctions}

The practice of discrimination and of anti-discrimination measures is multifarious. There are different distinctions in the qualification of the principle of equality in practice, which are worth a brief detour. They will be presented in three categories: the types of duties of equality (i.), the duty-holders of these duties (ii.) and the content of these duties (iii.). Finally, I will briefly mention a distinction within formal equality, that between equality before and in the law (iv.).

\section{i. Types of duties: negative and positive duties of equality}

Equality and non-discrimination may call for negative duties of abstention from discrimination, but also for positive duties to ensure equality and the absence of discrimination, such as measures of information or encouragement. Positive duties of equality should not be confused with positive duties of protection which apply to all human rights and, more importantly, equally to negative and positive duties of equality. These positive duties of protection indeed imply taking positive action for protection on the part of authorities that should actively prevent discrimination from occurring (negative duties), but also take positive measures for promotion of equality (positive duties).

\section{ii. Duty-holders: vertical and horizontal effect of equality}

An important question that has gradually moved centre stage with more and more human rights violations being perpetrated by individuals is the possibility of invoking the principle of non-discrimination directly against individuals. This is also what one refers to as the horizontal effect of the principle, as opposed to its application to vertical relationships between the State and individuals.

This is a very controversial question in domestic law, that has not been fully resolved yet (Besson, 1999). At the international level, things remain largely unclear since States are the only parties to international conventions and hence the only direct holders of the duties they give rise to. Thus, direct horizontal effect has never been granted to the anti-discrimination principle of international law. This is due mainly to the way international courts and bodies responsible for the implementation of the conventions at stake function: their jurisdiction usually only applies to States Parties. If such a horizontal 
effect were to be granted, however, it could be through national direct horizontal effect of human rights when such an effect is admitted at national level. In the absence of direct horizontal effect, international guarantees of the principle of non-discrimination are generally regarded as having an indirect horizontal effect. In this sense, they should be used by judges and official authorities to interpret private law and the law regulating inter-individual relationships in a way that prohibits discrimination among private parties. It is important, however, not to confuse the obligation of individuals not to discriminate against other individuals, whether it occurs directly or indirectly, with the more general positive obligation of the States Parties to prevent these individuals from discriminating by prohibiting discrimination through their legislation and other practical measures.

\section{iii. Content of duties: Formal and material equality}

Equality may be deemed formal when what matters is the different treatment of similar situations or the similar treatment of different situations seen in strict terms. By contrast, material or substantive equality is focused on de facto equality. Thus, whether or not someone is formally discriminated against and treated differently, what matters for material equality is whether she is treated differently in practice. ${ }^{8}$ For instance, men and women may be treated equally from a formal perspective, but be treated differently materially when their positions are judged from a practical standpoint. In what follows, I will present different categories of material equality through distinctions between equality of opportunities and equality of results (a)), between symmetrical and asymmetrical equality (b)), and between direct and indirect equality (c)).

a) Equality of opportunities and equality of results

When one is concerned with material equality, one usually opposes equality of opportunities to equality of results. Whereas the former is an equality of starting gates, as when men and women are given equal education, the latter looks at results, as when men and women have not fared equally well overall in the labour market, although they have been given equal chances. Measures of protection of equality may focus on the former or the latter, depending on the overall policy one follows. Promoting equality of opportunities is usually regarded as less damaging for formal equality than targeting inequalities of result. ${ }^{9}$

b) Symmetrical and asymmetrical equality

When equality calls for the equal treatment of similar situations and the differentiated treatment of different situations, it is referred to as symmetrical equality. Equal treatment does not necessarily mean identical treatment in every instance, however (Bayefsky, 1990, p. 11). ${ }^{10}$ Some persons or situations 
may call for special measures of protection and favourable treatment. When it justifies special protection of people with special needs, one speaks of asymmetrical equality. This opposition between symmetrical and asymmetrical equality corresponds to two successive trends in the history of the development of anti-discrimination law: first of all, the idea that equality implies similarity and, secondly, the idea that equality implies, on the contrary, diversity.

Whereas negative duties of non-discrimination are necessarily symmetrical, it is not the case of positive duties for promotion of material equality. Positive duties may indeed be undifferentiated and target all groups indifferently as with general education programmes or other active promotions of equality which benefit everybody. But they may also, and this is more controversial, favour discriminated groups over others, thus discriminating formally in order to redress material discrimination. In a nutshell, there are two groups of asymmetrical positive measures one may think of depending on their degree of asymmetry. First of all, special protection measures which are selective and address special needs (Bayefsky, 1990, pp. 24-27). It suffices to think of measures of protection of pregnant women or of disabled people to see how some differences may call for the discrimination of some women or some people when compared to others in a similar situation simply by virtue of their special needs. Secondly, there are also measures of affirmative or positive discrimination which aim at redressing the situation of material inequality of some groups overall and go further than special protection measures (Bayefsky, 1990, pp. 27-33). An example is that of the measures promoting a higher representation of women or minority members in the labour market or political institutions. Positive measures openly discriminate formally in favour of certain people in order to eliminate conditions which cause or perpetuate discrimination in practice.

Special measures of protection are very controversial, since they allegedly discriminate formally against those who do not have special needs and may even be said to discriminate those who have those needs, but whose difference is accentuated in this way. Positive discrimination measures have attracted further critiques of the same kind. They are therefore, first of all, usually only justified for a limited period of time as long as they are necessary to correct past discrimination in practice. They should, moreover, be accompanied by other measures which focus on other levels of the discrimination process than on its results. Finally, they should be targeted at a special group and never be absolute." New trends in anti-discrimination law have been identified recently, and in particular more inclusive rights and mainstreaming. They reject the differentiating approach to adopt more inclusive measures which protect neutral activities such as parenthood instead of motherhood or an inclusive right to education instead of a right to special education for disabled people. 
c) Direct and indirect discrimination

A further distinction pertaining to the opposition between formal and material equality is that of the opposition between direct and indirect discrimination. There are indeed, next to cases of direct and open discrimination, cases in which the differentiation of similar situations is intentional but is not directly founded on suspect grounds. As such, it is prima facie justified. Materially, however, such situations may be discriminatory because the grounds of differentiation are covert discriminatory grounds. These are cases of so-called indirect discrimination, i.e. differentiations that use seemingly innocuous grounds to differentiate between similar situations and hence effectively discriminating people on suspect grounds. For instance, an employer may discriminate between full-time and part-time employees on grounds of the effective working time, which is at first at least a perfectly innocuous and justified ground of differentiation, but this may in effect lead to discriminating women who constitute most part-time employees.

iv. A case of formal equality: equality before and in the law

Finally, it is worth addressing a major case of formal equality: legal equality or equality de jure. There are two kinds of equality that arise in the legal domain. First of all, equality before the law pertains to the status of a person when the law applies to her. For instance, equality before the law is in question when the quality of legal subject is equally distributed. Secondly, equality in the law by contrast is the equality the law guarantees in effect. For instance, equality in the law can be exemplified by the equal treatment of the duties of men and women in family law.

\section{The principle of non-discrimination in international human rights law}

The importance of the non-discrimination principle has been recognized in almost all international human rights instruments since the 1950s. The three major international human rights instruments, i.e. the 1948 Universal Declaration of Human Rights, the 1966 International Covenant on Civil and Political Rights and the 1966 International Covenant on Economic, Social and Cultural Rights protect the principle in a central place. The 1945 Charter of the United Nations itself includes as two of its major goals the principle of equal rights of peoples and the promotion and encouragement of respect for human rights and fundamental freedoms. In fact, the principle of non-discrimination also constitutes a norm of customary international law ${ }^{12}$ and even, according to some authors, a norm of jus cogens at least with respect to discrimination 
based on race and sex (McKean, 1983, pp. 277-283; Hitch, 1989, p. 50; Ramcharan, 1983, p. 249; Van Bueren, 1995, p. 55).

The importance which has been given to this principle by the United Nations since its inception, and by the world community in general, can be confirmed both by the frequency with which the principle is included and the prominence it has been given being usually placed at the beginning in each instrument. These anti-discrimination norms are often general blanket norms, which prohibit discrimination across the board, but they can also be contextspecific $^{13}$, as in the case of the prohibition of discrimination in education, or ground-specific ${ }^{14}$ as in the case of the prohibition of discrimination based on gender or race. In what follows, I will present four major international guarantees of the principle of non-discrimination and their common features (a.), before addressing their applicability in the context of child discrimination (b.).

\section{a. Major international guarantees of the non-discrimination principle}

This section presents four major guarantees of the principle of nondiscrimination in international instruments which are spread out in universal UN instruments, but also in regional instruments like the ECHR. After a short description of their texts (i. to iv.), I will highlight their common features (v.).

\section{i. The Universal Declaration of Human Rights}

There are two articles worth mentioning in the 1948 Universal Declaration of Human Rights (UDHR). According to art. 2 UDHR:

Everyone is entitled to all the rights and freedoms set forth in this Declaration, without distinction of any kind, such as race, colour, sex, language, religion, political or other opinion, national or social origin, property, birth or other status.

This general principle of non-discrimination is specified further in the legal context, according to art. 7 UDHR:

All are equal before the law and are entitled without any discrimination to equal protection of the law. All are entitled to equal protection against discrimination in violation of this Declaration or against any incitement to such discrimination.

\section{ii. The International Covenant on Civil and Political Rights}

Two articles should be mentioned in the 1966 International Covenant on Civil and Political Rights (ICCPR). According to art. 2 par. 1 ICCPR:

Each State Party to the Present Covenant undertakes to respect and to ensure to all individuals within its territory and subject to its jurisdiction the rights recognized in the present Covenant, without distinction of any kind, such as race, 
colour, sex, language, religion, political or other opinion, national or social origin, property, birth or other status.

This general principle is specified further in the legal context according to art. 26 ICCPR:

All persons are equal before the law and are entitled without any discrimination to the equal protection of the law. In this respect, the law shall prohibit any discrimination and guarantee to all persons equal and effective protection against discrimination on any grounds such as race, colour, sex, language, religion, political or other opinion, national or social origin, property, birth or other status.

iii. The International Covenant on Economic, Social and Cultural Rights There is one article worth mentioning in the 1966 International Covenant on Economic, Social and Cultural Rights (ICESCR). According to art. 2 par. 2 ICESCR:

The States Parties to the present Covenant undertake to guarantee that the rights enunciated in the present Covenant will be exercised without discrimination of any kind as to race, colour, sex, language, religion, political or other opinion, national or social origin, property, birth or other status.

\section{iv. The European Convention on Human Rights}

Two articles should be mentioned in the 1950 European Convention of Human Rights (ECHR). According to art. 14 ECHR:

The enjoyment of the rights and freedoms set forth in this Convention shall be secured without discrimination on any ground such as sex, race, colour, language, religion, political or other opinion, national or social origin, association with a national minority, property, birth or other status.

According to art. 1 of the Protocol 12 ECHR on the general prohibition of discrimination, which has not entered into force yet, but which extends the scope of application of art. 14 ECHR:

1. The enjoyment of any right set forth by law shall be secured without discrimination on any ground such as sex, race, colour, language, religion, political or other opinion, national or social origin, association with a national minority, property, birth or other status.

2. No one shall be discriminated against by any public authority on any grounds such as those mentioned in paragraph 1 .

\section{v. Common features}

These four international guarantees of the non-discrimination principle share common features. First of all, most of them are subordinate and nonautonomous clauses, which qualify other guaranteed rights in recommending their respect free of any discrimination rather than prohibiting discrimination in itself (Bayefsky, 1990, pp. 3-4). ${ }^{15}$ This is the case, for instance, of art. 2 
par. 2 ICCPR, art. 2 par. 1 ICESCR, art. 2 UDHR and art. 14 ECHR. Exceptions to this may be found in art. 26 ICCPR and art. 1 Protocol 12 ECHR. They guarantee equality before the law and equal protection of the law in themselves, not merely in the context of a threat to another substantive Covenant or Convention right or freedom.

Secondly, most of these guarantees are not directly justiciable norms. In this sense, they are usually programmatic and cannot be invoked directly by individuals either against the State or other individuals. Exceptions to this may be found in art. 26 ICCPR, art 14 ECHR and art. 1 Protocol 12 ECHR. Finally, most of these dispositions have an open-ended as opposed to a selfcontained scope. In this sense, the list of prohibited discrimination grounds is purely indicative and can be extended to other similar grounds (Bayefsky, 1990 , pp. 5-8). This is what is meant by terms such as 'other status' or 'such as' in the non-discrimination clauses. The list of prohibited discrimination grounds is more or less the same in all the guarantees mentioned.

\section{b. Extension of these guarantees of non-discrimination to children}

In principle, children are included and protected by the general antidiscrimination clauses of international instruments just as adults are (Marks/Clapham, 2005, p. 26). The question, however, whether children are sufficiently protected by the anti-discrimination clauses of major international human rights instruments is not an easy one to solve and relates to the specific situation of children as victims of discrimination.

Children often require special measures of protection that take into account their particular vulnerability vis-à-vis the State, but also vis-à-vis their families and other individuals. Children may indeed be discriminated against because of actions that their parents or family members have engaged in and hence in a way that is mediated through their parents. Moreover, children are often discriminated against in ways that reflect their specific position in society, i.e. through punishment, for instance. Furthermore, children are often not only discriminated against when compared to other children, but also by comparison to adults. For instance, children are excluded from actively taking part in judicial procedures through which they could claim their rights not to be discriminated against. Finally, children are often doubly discriminated against: first, as children and, second, as members of a specific gender or group. This is the case, for instance, of certain differentiations based on age for sexual consent between homosexual and heterosexual acts, which have been thought to protect young adults and hence deemed justified, but which have turned out quite detrimental to homosexual young adults (Van Bueren, 1995, pp. 39-40). ${ }^{16}$ This 'double jeopardy' is more difficult to handle by general guarantees of the principle of non-discrimination and needs to be addressed specifically. 
Before turning to child-specific anti-discrimination norms, it is worth emphasizing that general international human rights instruments also provide for special measures of protection of children that help fight against child-specific discrimination. One should mention two lex specialis, which extend the applicability of general non-discrimination clauses to children. ${ }^{17}$ For instance, art. 24 par. 1 ICCPR states that

Every child shall have, without any discrimination as to race, colour, sex, language, religion, national or social origin, property or birth, the right to such measures of protection as are required by his status as a minor, on the part of his family, society and the State.

This norm is restricted, however, to foreseeing the possibility of arranging special protection measures in favour of children and the need to ensure the absence of discrimination in these special measures. This specific approach is confirmed by Art. 10 par. 3 ICESCR:

Special measures of protection and assistance should be taken on behalf of all children and young persons without any discrimination for reasons of parentage or other conditions. Children and young persons should be protected from economic and social exploitation. Their employment in work harmful to their morals or health or dangerous to life or likely to hamper their normal development should be punishable by law. States should also set age limits below which the paid employment of child labour should be prohibited and punishable by law.

\section{The principle of non-discrimination in the Convention on the Rights of the Child}

The principle of non-discrimination has been insufficiently developed in international and regional human rights instruments for them to counter effectively child discrimination. This is due partly to these instruments' general misapplication and reservations, but also to their inadequacy to protect children against all kinds of child-specific discrimination. Hence the need for a special international instrument guaranteeing rights to children without discrimination. This was done in 1989 with the adoption of the Convention on the rights of the child and art. 2 CRC's guarantee of the principle of nondiscrimination. In what follows, I will start by presenting the emergence of art. 2 CRC (a.), before looking more closely at its text (b.), scope (c.), content (d.) and implementation (e.). Finally, I will present three specific dispositions relating to the discrimination of particularly vulnerable children (f.).

\section{a. The emergence of art. $2 C R C$}

One may say that the principle of non-discrimination has been a central driving force in the history of the development of the rights of the child since 
well before 1989. This may be seen at different levels, from a very general one to a more concrete non-discrimination guarantee. First of all, the discrimination between children and adults. The principle of non-discrimination has clearly been at work in the gradual recognition of children's rights tout court (Marks/Clapham, 2005, p. 19; McGillivray, 1994; Archard, 2002; Griffin, 2002). For long, indeed, children were not deemed as capable rightsholders and were hence discriminated against by comparison to adults. Slowly, but surely, children's rights have been recognized and this recognition culminated in the adoption of the CRC in 1989. Children's interests are now deemed as equally fundamental to those of adults, and even sometimes as more fundamental and hence in more need of protection. Secondly, the discrimination between children and young adults. A second step in the protection against discrimination of children has taken place through the definition of the 'child'. This is still a very controversial question given art. 1 CRC's incomplete definition of the 'child' (Grover, 2004). Finally, the discrimination between children and children. A final step in the struggle against discrimination of children has been made when the general clause of anti-discrimination of art. $2 \mathrm{CRC}$ was adopted. It guarantees indeed the equal benefit of all Convention rights without discrimination. In this sense, the Convention adds an additional express ground by which states are under a duty not to discriminate against children in their enjoyment of the Convention's rights.

A question one may raise of course is that of the possible 'ghettoization' of children's rights issues through the prohibition of discrimination of children in a special Convention (Hitch, 1989, p. 54). One has noticed, for instance, how the discrimination of girls has gradually become a separate issue from that of women and hence has been addressed through different standards. Although this may have benefited girls, it also means that genderoriented measures lack coherence overall and has led to occulting some sensitive issues such as abortion by young women, for instance. It is important to mention art. $41 \mathrm{CRC}$, however, which is a 'favour clause' that gives priority to more favourable international clauses over less protective norms in the CRC. Moreover, the fact that art. $2 \mathrm{CRC}$ adopts a similar structure and wording to existing anti-discrimination clauses in international law shows a clear intention to keep in line with what is done in international anti-discrimination law. ${ }^{18}$

Like other international instruments, the Convention on the Rights of the Child guarantees the principle of non-discrimination in many places. Art. 2 $\mathrm{CRC}$ is the most important and general clause of non-discrimination. It belongs to the so-called general principles of the CRC with art. 1 to 5 and 41 CRC. As such, it applies to the interpretation and application of the whole Convention and to the many ways in which other rights may be applied in a discriminatory fashion (Muscroft, 2000, pp. 27-28). The non-discrimination 
principle may also be found, however, in art. $22 \mathrm{CRC}$ relating to the special protection of refugee children, in art. $23 \mathrm{CRC}$ relating to the special protection of disabled children or art. $30 \mathrm{CRC}$ relating to the special protection of indigenous children. I will come back to these lex specialis at the end of the presentation of art. 2 CRC on which I will focus from now on. Finally, one finds echoes of the non-discrimination principle in different other dispositions like art. $28 \mathrm{CRC}$ in the context of the right to education.

\section{b. The text of art. $2 C R C$}

The text of art. 2 CRC reads as follows:

1. States Parties shall respect and ensure the rights set forth in the present Convention to each child within their jurisdiction without discrimination of any kind, irrespective of the child's or his or her parent's or legal guardian's race, colour, sex, language, religion, political or other opinion, national, ethnic or social origin, property, disability, birth or other status.

2. States Parties shall take all appropriate measures to ensure that the child is protected against all forms of discrimination or punishment on the basis of the status, activities, expressed opinions, or beliefs of the child's parents, legal guardians, or family members.

Art. $2 \mathrm{CRC}$ is a complex article. Its two paragraphs are articulated along three dimensions. First of all, the grounds of discrimination. Whereas the first paragraph protects against discrimination based on any of the mentioned grounds as well as others, the second paragraph only relates to specific grounds of discrimination related to the person or status of the child's parents or guardians. Secondly, the rights protected. Whereas the first paragraph protects only those rights guaranteed in the Convention, the second paragraph protects against any kind of discrimination, thus being non-subordinate and autonomous. Finally, the obligations foreseen. Whereas the first paragraph generates negative obligations of respect and positive obligations of result, the second paragraph deals exclusively with positive obligations of result.

A careful reading of the international provisions discussed before shows that, although the wording of art. $2 \mathrm{CRC}$ is very similar to that in several other international human rights guarantees of the principle of non-discrimination, such as art. 2 par. 1 ICCPR or art. 2 par. 2 ICESCR, it is also unique in several ways. First of all, art. 2 protects the child against discrimination directly targeted at her, but also against discrimination based on attributes of the child's parents, legal guardians or family members. Very often, indeed, children are easy targets of discrimination through their parents. Thus, the article recognizes both the special status and needs of children, due to their very dependency, and at the same time their right to many of the same basic human rights and fundamental freedoms already recognized to adults. As 
such, it is a child-specific anti-discrimination clause. Secondly, the list of prohibited grounds of discrimination in art. 2 par. 1 is the same as those of major non-discrimination clauses with the additional ground of disability. Thirdly, Art. 2 is a directly justiciable clause, whose content is not only programmatic, but may be invoked by victims of discrimination as an immediately realizable right. This mirrors the solution chosen by art. 2 par. 1 ICCPR where the rights recognized form an immediate obligation of result. An important exception has to be carved in this rule, however, regarding the realization of economic, social and cultural rights. Fourthly, Art. 2 uses the term 'discrimination' like art. 2 par. 2 ICESCR and art. 14 ECHR, by contrast to art. 2 par. 1 ICCPR and art. 2 UDHR which refer to 'distinction' (Hitch, 1989, pp. 54-58). It is generally accepted nowadays that both refer to the same kind of differentiation without reason. Fifthly, the scope of application of art. 2 is open-ended and cannot be limited to some areas only. It applies to education as much as to private ownership. Finally, it is important to emphasise that art. 2 par. 1 is a subordinate rather than an autonomous clause of non-discrimination. As such, it applies only to those rights guaranteed in the Convention, by contrast to art. 26 ICCPR, for instance. In this sense, it is very similar to art. 2 par. 1 ICCPR, art. 2 par. 2 ICESCR and art. 14 ECHR. This is not the case, however, as we have already seen, of art. 2 par. 2 CRC which applies to all cases of discrimination of a child grounded on his parents' activities or status.

\section{c. The scope of art. 2 CRC}

If one looks more carefully at the implications of art. 2 CRC, its specific material (i.), personal (ii.) and territorial scope (iii.) need to be delineated.

\section{i. Material scope}

The material scope of art. 2 CRC can be apprehended from the perspective of the rights protected (a)), but also from that of the areas covered (b)) and that of the prohibited grounds of discrimination (c)).

\section{a) Rights protected}

The phrase 'the rights set forth in the present Convention' in art. 2 par. 1 indicates that the obligation of non-discrimination applies with respect to all the rights set forth in the CRC. All the rights in the Convention can indeed be respected in ways which exclude or discriminate some children. The CRC's principle of non-discrimination is not an independent and autonomous principle of non-discrimination, but a derivative one, like most principles guaranteed in international instruments. There is an exception to this restriction, however, in art. 2 par. 2 which extends to any rights and areas where discrimination may take place, even if they fall outside the ambit of the 
Convention. This disposition has very large implications, which have still been largely unexploited.

\section{b) Areas covered}

Depending on the duties at stake, the obligation of the State has a different material scope. When the obligation is one of negative 'respect' of equality according to art. 2 par. 1, the obligation applies to any governmental measure of State action by an official or authority at any level of government. When the obligation is one of positive results according to art. 2 par. 1 and 2, however, the obligation extends also to removing private obstacles to the enjoyment of the designated rights.

c) Grounds of discrimination

A long list of suspect classifications and discrimination grounds is given in art. 2 par. 1 CRC. Art. 2 par. 2 only applies, by contrast, to the discrimination of children that is based on the status of their parents.

Art. 2 par. $1 \mathrm{CRC}$ repeats the suspect classifications foreseen in most human rights international instruments, such as the UDHR, the ICCPR, the ICSCR and the UNESCO Convention against Discrimination in Education, but adds a new important ground of discrimination: disability. This list is only indicative and is not exhaustive. As such, it does not preclude further grounds. Recent developments show that sexual orientation and HIV/Aids have also become prohibited grounds of children's discrimination (Hodgkin/Newell, 2002, p. 29). There was mention at some stage in the travaux préparatoires of the need to protect non-marital children expressly against discrimination when compared to marital children, but this was not done in the end for lack of consensus. It is clear, however, that this ground of discrimination could be deduced from others in art. 2 which is not exhaustive, but also from other international and regional guarantees against discrimination (LeBlanc, 1995, pp. 100-101; Van Bueren, 1995, pp. 41-45; Detrick, 1999, pp. 75-77). In fact, art. 41 encourages the most liberal interpretation of the convention's articles by stating that nothing in the convention affects any provisions of domestic law or international agreements that are 'more conducive to the realization of the rights of the child.' A final point to emphasise is the child-specificity of this list. It indicates indeed that the prohibition against discrimination is irrespective of the "child's or his or her parents' or legal guardian's' race, colour, gender, language, etc.

\section{ii. Personal scope}

a) Right-holders

Those protected by art. 2 CRC are all children. As such, art. 2 depends on art. 1 CRC's definition of 'child'. This definition regards any person under 18 
as a child, except when national law determines a different age for the children's majority. This has been heavily criticized for leaving a certain scope for discrimination among children of different States Parties. One may argue, however, that the definition of the Convention is already quite self-standing, which is a progress when compared to the multitude of definitions which used to prevail.

The children protected may not be discriminated against therefore because they are non-nationals of the State in which they are discriminated. Foreign children may invoke art. 2 against a State which has ratified the Convention just as a national child, provided, of course, they fall under that State's jurisdiction. This applies even if they are in irregular situation. The only exceptions to the general scope of rights-holders of art. 2 are art. 22 and 23 CRC which offer special protection respectively to refugee and disabled children. Only children falling into these groups may therefore benefit from the special protection measures foreseen by these articles, thus giving rise to interesting questions of discrimination within the anti-discrimination clause, as we will see.

\section{b) Duty-holders}

From a purely practical point of view, discrimination may have many perpetrators. First of all, the State. It is indeed the source of power that can most discriminate or omit to prevent discrimination from occurring. Secondly, parents or guardians. They constitute another important source of discrimination, as they dispose legally and materially of important power over children. Thirdly, other individuals. Other individuals in the society may also contribute to discriminating against children. This is the case of the media or of other social groups such as religious lobbies which contribute to entrenching biases against children in social attitudes (Muscroft, 2000, p. 35; Lansdown, 2001, pp. 22-23). Finally, other children. Children are also often at the origin of discrimination against other children.

In terms of legal duties stemming from these actions or omissions, things are slightly more complicated, however. The States Parties are indeed clearly the primary negative and positive duty-holders of art. 2 par. 1 and 2 CRC. With respect to individual discriminators, the question arises therefore as to whom should be sought in justice to reply from violations of the Convention. Can the parents, other adults or children be attacked directly on grounds of the violation of art. $2 \mathrm{CRC}$ or, on the contrary, should the State be the only one to reply from its lack of prevention of their discrimination? This is the question of the horizontal effect of Art. 2. As in the context of national and international anti-discrimination law in general, it is useful to distinguish between direct and indirect horizontal effect. The question of the direct horizontal effect of art. 2 has not been clearly answered yet. It should be clear, however, that art. 2 should have an indirect horizontal effect in the interpretation of 
the Convention's rights, for instance through the national application of the Convention. Moreover, the State should in any case be responsible in case of violation of its positive duties to prevent legally or practically individuals from discriminating against children. The Committee on the rights of the child has often repeated that the principle of non-discrimination applies equally to private institutions and individuals, as well as to the State and that this must be reflected in legislation.

\section{iii. Territorial scope}

Art. 2 par. 1 CRC mentions that it applies to all children under the State's jurisdiction. This is a very broad clause, that was thoroughly debated in the travaux préparatoires, which excludes limiting the rights protected only to those children on the territory of the State Party or only to national children as opposed to foreign children. The jurisdiction of a State Party may indeed extend to national and foreign children inside and outside its territory when that territory is occupied or protected by the State. What matters for the State's jurisdiction is the authority or responsibility de facto rather than de jure of the State Party (Alston, 1992, p. 5; Detrick, 1999, p. 71). This is also what is done in the context of the European Convention on Human Rights. ${ }^{19}$

This applies whether the discriminated child is under the State's jurisdiction regularly or not (LeBlanc, 1995, pp. 95-96). As such, the Convention specifically addresses the rights of vulnerable groups of children, such as refugee children, children in trouble with the law, children in situations of armed conflict and children from minority groups. Finally, Art. 2 CRC applies to children under a State Party's jurisdiction whether or not the State from which this child is a national has ratified the Convention. The only exceptions to this general rule are those foreseen in Art. $22 \mathrm{CRC}$ which deals with refugee children (Detrick, 1999, pp. 69-70).

\section{d. The content of art. 2 CRC}

\section{i. General principle}

Like most international instruments, the CRC does not define what it means by 'discrimination'. Nor has the Committee on the rights of the child yet issued a general comment on art. 2. In its first general comment, issued in 2001, the Committee stated, however, that 'discrimination on the basis of any of the grounds listed in article 2 of the Convention, whether it is overt or hidden, offends the human dignity of the child and is capable of undermining or even destroying the capacity of the child to benefit from educational opportunities $^{20}$. As argued before, the principle of non-discrimination prohibits treating differently similar situations without an objective justification. The four elements in the definition should be re-assessed in a child-specific context. 
First of all, as in the general case, discrimination in the context of children's rights implies a difference of treatment of similar situations or a similar treatment of different situations, whether this discrimination is intentional or not (Alston, 1992, p. 6). When one determines whether situations are alike and should therefore be treated alike, it is important to determine what should be the criterion of comparison. The general case is a comparison between children. Thus, for instance, girls should not be treated differently from boys at school. A special case one may mention, however, is that of a comparison between children and adults. Thus, for instance, children should not be discriminated against on grounds of property ownership when only adults are allowed to hold property in a specific legal order. The difference of treatment or distinction at stake may cover any kind of treatment one may think of. Art. 2 par. 2 CRC mentions a special form of discrimination, i.e. any form of punishment related to the child's parents' or guardians' status. This is an additional child-specific dimension of the principle of non-discrimination that focuses on the fact that children are often discriminated in ways which match their specific position in human society. Children have indeed become the victims of human rights violations, including imprisonment or torture because of actions that their parents or family members have engaged in (LeBlanc, 1995, p. 97).

Secondly, not all differences in treatment are discriminatory. Only those which lack an objective justification are. The same kind of objective justification may be provided as in the general case of discrimination and one often encounters positive action measures in the context of anti-discrimination protection of the child that discriminate against other children on legitimate grounds. Interestingly, art. $3 \mathrm{CRC}$ and the best interests of the child may be understood as a test against which to judge the justification of discriminatory measures (Muscroft, 2000, p. 30). It does not work as a blanket justification of all discrimination, but helps demonstrate how a discriminatory measure may help promote the best interests of the child through enhancing and protecting their rights. Thirdly, a difference of treatment must not only pursue a legitimate aim to be a justified distinction. There must also be a reasonable relationship of proportionality between the means employed and the aim sought to be achieved. Finally, a long list of suspect classifications and discrimination grounds is given in art. 2 par. 1 CRC. As I explained before, this list is only indicative and not exhaustive.

\section{ii. Formal and material equality}

Art. 2 CRC protects equality among children in a more flexible and open way than previous general guarantees of equality in major international human rights instruments (Alston, 1992, p. 1). It generally prohibits measures which treat differently similar situations and vice-versa. As such, it clearly protects 
formal equality and requests negative measures of non-discrimination. It does not, however, require identical treatment in all circumstances. As such, not only does art. 2 protect both formal and material equality, but it may also justify asymmetrical measures of equality.

One may distinguish two kinds of positive measures of promotion of material equality according to art. 2 . Some situations may call for specific protection measures to redress past material inequalities, even if this implies violating formal equality. This is even more important in the case of children than in the general context, as children are a vulnerable category of people whose past discrimination may have even greater consequences on their material equality. This is what the Preamble to the CRC states when it recognizes that 'in all countries of the world, there are children living in exceptionally difficult conditions, and that such children need special consideration'. Imagine, for instance, the case of children with impaired mental capacities who must be specially protected even if this discriminates formally other children in the same situation. This is what the special measures art. 22 and 23 foresee in the case of the special protection of disabled and refugee children. The promotion of material equality may be exemplified by another type of positive measures: affirmative action or positive discrimination. Art. 2 does not exclude affirmative action measures, which openly favour some children over others to redress past material inequalities, although it does not foresee them expressly by contrast to what anti-discrimination clauses in other conventions do (Hitch, 1989, p. 60). An example of affirmative action may be the establishment of promotion mechanisms of rural or disabled children in urban and regular schools to promote their inclusion and redress past material inequalities.

Of course, affirmative action in the context of children's discrimination is as controversial as elsewhere. The CRC was adopted in 1989 at a time when protective measures of equality were regarded as ideal measures of promotion of material equality. More sensitive and inclusive measures foreseen by the third generation of anti-discrimination laws might, however, be preferred nowadays (Muscroft, 2000, pp. 41-49; Lansdown, 2001). Although one may understand the need for measures of special care, there is a sense in which claiming that some children have special needs and that they are somehow different is in itself discriminatory both against them and other children. A preferred solution would therefore be to promote the right to inclusive education whatever measures this takes to extend it to disabled children (Lansdown, 2001, pp. 18-20).

\section{iii. Direct and indirect discrimination}

Art. 2 CRC prohibits cases of direct discrimination, but also indirect discrimination, i.e. differentiations that use seemingly innocuous grounds to differentiate between similar situations and hence effectively discriminate 
against people on suspect grounds. For instance, a disabled child may be indirectly discriminated against by a rule which requires written work as an admission test to a school. True, formally speaking, this ground of discrimination is perfectly innocuous and admissible in an educational context. However, seen from the perspective of a disabled child, it might constitute an insurmountable obstacle in the access to further education and integration (Lansdown, 2001, p. 21).

\section{iv. Equality before and in the law}

By contrast to art. 26 ICCPR, art. 2 CRC does not expressly guarantee the concept of equality before the law. This could have been done by the express recognition of the child's legal personality. This is only an apparent lacuna, however. Moreover, such a guarantee would have somehow fallen outside the scope of a derivative clause like that of art. 2 (Van Bueren, 1995, p. 40). Finally, art. 12 par. 2 CRC's guarantee of the right of the child to participate in procedures and be heard seems to confirm that the child has legal personality. Legal personality is indeed the first step towards equality, with the second step being the granting of sufficient procedural capacity to protect that equality (Van Bueren, 1995, p. 45).

By contrast, Art. 2 guarantees equality in the law, as this flows from the Committee on the rights of the child's guidelines and its monitoring of States Parties' legislation for violations of equality (Hodgkin/Newell, 2002, p. 23). This is confirmed by art. 4 CRC's duties of implementation of equality that mention legislative duties of implementation.

\section{e. The implementation of art. $2 C R C$}

The implementation of art. 2 CRC gives rise to duties (i.) the respect of which is assessed through an international monitoring process (ii.) and national judicial control (iii.).

\section{i. Implementation duties}

Art. 2 CRC gives rise to detailed implementation duties (a)) that are complemented by positive duties of protection (b)) and are directly justiciable (c)). I will conclude by a short excursus on the admissibility of the budgetary exception in discrimination cases (d)).

\section{a) Art. 2 combined with art. $4 \mathrm{CRC}$}

Art. 2 CRC entails more than an anti-discrimination clause; it also has another albeit connected function in the determination of the scope of the obligations of the States Parties. This general function of art. 2 is very close to that of art. 4 which deals with the implementation of the Convention 
rights. One may even say, with Alston, that art. 2 par. 1 states the objectives of the Convention, while art. 4 gives the means to implement them (Alston, 1992, p. 4).

Like Art. 2 par. 1 ICCPR, art. 2 par. 1 CRC foresees two kinds of obligations which complement each other (Detrick, 1999, pp. 68-69). First of all, duties of respect. These duties are rather passive or negative and imply that the State may not discriminate in any way against children in their protected rights. Secondly, duties of result. These duties go further and are more active or positive (Hodgkin/Newell, 2002, p. 22). These positive duties are complemented by the duties set by art. 2 par. 2 CRC in relationship to grounds of discrimination related to the child's parents' or guardians' person or status. They imply that the State take all necessary measures to ensure for each child a discrimination-free enjoyment of all Convention rights. Addressing discrimination may require changes in legislation, administration and resource allocation, as well as educational measures to change attitudes in the media and the private sphere (Muscroft, 2000, pp. 33-35). This is confirmed by art. 4 CRC which emphasizes that legislative measures are not the only ones the State should take to combat discrimination like other violations of the Convention.

b) Positive duties of protection

All these duties, whether negative or positive, are complemented by positive duties of protection, which add a positive layer even to those negative duties to abstain from discriminating (Alston, 1992, pp. 4-5). They are duties to prevent discrimination from occurring, whether through governmental or private action.

This can take place legally through the adoption of anti-discrimination laws (Hodgkin/Newell, 2002, p. 23). Often, however, anti-discrimination laws exist, but are not effectively implemented (Muscroft, 2000, p. 34). Moreover, practical measures should also be taken to combat and prevent discrimination that cannot only be eradicated through laws, as in the context of social, economic and cultural rights, for instance. Socially internalised forms of discrimination and the media are indeed at the origins of many discriminations and should be targeted directly (Hodgkin/Newell, 2002, p. 24). It is important to emphasise that positive duties of protection apply to all areas of political control, whether official or private, thus calling for mainstreaming measures in all these areas.

c) Direct justiciability

Art. 2 CRC is directly justiciable and may be invoked by victims of discrimination as an immediately realizable right. This mirrors the solution chosen by art. 2 par. 1 ICCPR where the rights recognized form an immediate obligation 
of result (Detrick, 1999, p. 69). An important exception has to be carved in this rule, however, regarding the realization of economic, social and cultural rights. Art. 4 CRC foresees indeed that the drafters wished to incorporate an obligation of progressive achievement of these rights, along the lines of art. 2 par. 1 ICESCR. This raises difficult questions of control of their implementation, however (Detrick, 1999, p. 69).

d) The budgetary exception

According to the Committee on the Rights of the Child, the application of Art. 2 CRC 'cannot be made dependent upon budgetary resources ${ }^{21}$ '. Budgetary resources are indeed an easy reply to the obligations established by Art. 2. This is because poverty is one of the main causes of discrimination against children. It is a particularly difficult question in the context of positive action and special protection measures according to art. 2 par. 1 and 2 CRC. Faced with this contingent limitation, however, the Committee requires that non-discrimination of children be an important element of budget-making at national level. It even offers its services to States Parties to help budgeting protection measures (Hodgkin/Newell, 2002, pp. 25-26).

An exception made to the non-recevability of the budgetary exception is that of art. 4 CRC in the context of the application of the non-discrimination principle to economic, social and cultural rights. The latter is indeed limited by the extent of available resources. Art. 4 CRC also refers, however, to the international cooperation States Parties should have recourse to in case of financial difficulties (Alston, 1992, pp. 11-12). This cooperation can be both material and financial, although the conditional aspect of that aid may often discourage poor States from applying for it.

\section{ii. Monitoring}

States Parties' implementation duties are controlled primarily through the monitoring of the Committee on the Rights of the Child (Hodgkin/Newell, 2002, pp. 26-29). In fact, there is an entire section in the guidelines of the Committee on the Rights of the Child on the implementation of the principle of non-discrimination. As a result, the Committee has explicitly requested States Parties in their periodic reports to indicate the measures adopted pursuant to art. 2 CRC.

The section on art. 2 of its guidelines for periodic reports provides some insight into the Committee's views as regards the obligations of States Parties corresponding to the prohibition of discrimination. One may mention the following duties. First of all, the Committee requests States Parties to indicate in their reports whether the principle of non-discrimination is included as a binding principle in the Constitution or in domestic legislation specifically for children, and whether all the possible grounds of discrimination listed in 
art. 2 are reflected in such legal provisions. The Committee has already required States Parties to revise their national law in the past to adapt it to the requirements of art. 2. Secondly, and more generally, information is also requested on the steps taken, both in law and in practice, to prevent and combat discrimination. The Committee highlights, in particular, the need for data collection to be disaggregated to enable discrimination or potential discrimination to be identified. Finally, States Parties are also asked to indicate the specific measures adopted to reduce economic, social and geographical disparities, including those between rural and urban areas, and to prevent discrimination against the most disadvantaged groups of children.

\section{iii. Judicial control}

Last but not least, the implementation of art. 2 CRC may also be controlled judicially by national courts. They should indeed apply the Convention like any other national anti-discrimination law, when it is given primacy and direct effect in national law. This is the case, for instance, in Swiss law, where the discrimination between adopted children and children conceived artificially has given rise to a judicial change in constitutional law to recognise the absolute right to know one's origins independently of one's mode of conception (ATF 128 I 63; Besson, 2005).

\section{f. Lex specialis}

Besides art. $2 \mathrm{CRC}$, the Convention also guarantees expressly the right not to be discriminated against and even to be specially protected of specific groups of children, who might be particularly vulnerable to discrimination. I will only look at three groups here and very briefly so: refugee children (i.), disabled children (ii.) and indigenous children (iii.).

\section{i. Art. 22 CRC: refugee children}

Besides their protection in art. 2 CRC which applies, as we have seen, to all children under a state's jurisdiction even if they are foreigners and in irregular situation, refugee children are more specifically protected against discrimination by art. $22 \mathrm{CRC}$. This article reads as follows:

1. States Parties shall take appropriate measures to ensure that a child who is seeking refugee status or who is considered a refugee in accordance with applicable international or domestic law and procedures shall, whether unaccompanied or accompanied by his or her parents or by any other person, receive appropriate protection and humanitarian assistance in the enjoyment of applicable rights set forth in the present Convention and in other international human rights or humanitarian instruments to which the said States are Parties. 
This article develops the obligation of States Parties to ensure material equality of children and to take positive measures of promotion of equality when necessary. This article raises similar issues to those I mentioned before in relation to the discriminatory consequences of some asymmetric special protection measures aiming at ensuring material equality among children.

\section{ii. Art. 23 CRC: disabled children}

Children who are mentally or physically disabled are not only protected from discrimination under art. 2 CRC, but are also the beneficiaries of positive measures or special measures of protection prescribed by art. $23 \mathrm{CRC}$. This article reads as follows:

1. States Parties recognise that a mentally or physically disabled child should enjoy a full and decent life, in conditions which ensure dignity, promote selfreliance and facilitate the child's active participation in the community.

2. States Parties recognise the right of the disabled child to special care and shall encourage and ensure the extension, subject to available resources, to the eligible child and those responsible for his or her care, of assistance for which application is made and which is appropriate to the child's condition and to the circumstances of the parents or others caring for the child. [...]

This article develops the obligation of States Parties to ensure material equality of children and to take positive measures of promotion of equality when necessary. While the principle itself did not raise any controversies, the drafters expressed different opinions as to whom should be regarded as the duty-bearer. The compromise that emerged out of the travaux préparatoires were par. 2, 3 and 4 which establish the basic principles that guide assistance to disabled children within the context of available family resources augmented by national and international assistance (LeBlanc, 1995, p. 103). This compromise may not be deemed a very happy one, as it simply passes the buck to the private sphere, where we know incentives to combat discrimination are very rare (Lansdown, 2002, pp. 22, 29). Moreover, as I explained before, the potentially discriminatory consequences of special protection measures of disabled children have gradually discredited art. 23 among those who fight for the inclusion of disabled children (Lansdown, 2002, pp. 18-20).

\section{iii. Art. 30 CRC: minority and indigenous children}

The status of indigenous peoples has been the subject of discussion in various international fora in recent years. Discrimination against children of indigenous origin is not expressly prohibited under art. 2 CRC. However, such children may be covered under other terms used such as 'ethnic'. Besides, the list being not exhaustive, indigenous children may well be protected implicitly just like non-marital children (LeBlanc, 1995, p. 105). 
Finally, the problem of indigenous children is also addressed elsewhere in the Convention, including by art. $30 \mathrm{CRC}$ which states that:

In those States in which ethnic, religious or linguistic minorities or persons of indigenous origin exist, a child belonging to such a minority or who is indigenous shall not be denied the right, in community with other members of his or her group, to enjoy his or her own culture, to profess and practise his or her own religion, or to use his or her own language.

Like art. 23, art. 30 allows for special protection measures and positive action in favour of minority and indigenous children, with the difficulties this raises in terms of potential isolation and stigmatization of these children (Detrick, 1999, Art. 30).

\section{Conclusion}

More than fifteen years ago, the Convention on the Rights of the Child was adopted with a guarantee of the non-discrimination principle situated prominently in its art. 2. Retrospectively, this confirms that the emergence of children's rights has been the gradual conquest of equality, first of all, vis-à-vis adults, then in regard to young adults and, finally, by comparison to other children. Art. 2 captures the child-specific dimension of child discrimination and has been used most effectively against the latter. The principle of nondiscrimination of the child is guaranteed in a new protective way by art. 2 and other special norms in the Convention, that contrast with earlier international anti-discrimination clauses from the 1950s and 1960s. It should also have become clear by the end of this article, however, that, like other anti-discrimination clauses, art. $2 \mathrm{CRC}$ is growing old. Special protection measures can have destructive discriminatory consequences on particularly vulnerable children whose integration should be our foremost goal. New inclusive approaches are yet to be sought therefore to avoid the 'ghettoization' of some cases of child discrimination.

\section{References}

Alston, P., "Cadre juridique de la Convention relative aux droits de l'enfant", Bulletin des droits de l'homme 1992 (91(2)), 1-15.

Archard, D.W., “Childrens' Rights", Stanford Encyclopaedia of Philosophy, (2002), http://plato.stanford.edu/entries/rights-children/.

Bayefsky, A.F., "The Principle of Equality and Non-Discrimination in International Law", Human Rights Law Journal 1990 (11), 1-34.

Besson, S., L'égalité horizontale. L'égalité de traitement entre particuliers. Des fondements philosophiques au droit privé suisse (Fribourg: AISUF, 1999). 
Besson, S., "Das Recht auf Kenntnis der eigenen Abstammung - Wege und Auswirkungen der Konkretisierung eines Grundrechts", Revue de droit suisse 2005 (1), 39-71.

Breen, C., "Refugee Law in Ireland: Disregarding the Rights of the Child-Citizen, Discriminating against the Rights of the Child", International Journal of Refugee Law 2003 (15(4)), 750-785.

Brownlie, I., Principles of Public International Law (6th edn), (Oxford: Oxford University Press, 2003).

Van Bueren, G., The International Law on the Rights of the Child (Dordrecht: Kluwer, 1995).

Detrick, S., A Commentary on the United Nations Convention on the Rights of the Child (The Hague: Martinus Nijhoff, 1999).

Dinstein, Y., "Discrimination and International Human Rights", Israel Yearbook of Human Rights 1985 (15), 11-27.

Griffin, J., "Do Children Have Rights?", in D. Archard and C. Macleod (eds), The Moral and Political Status of Children: New Essays (Oxford: Oxford University Press, 2002).

Grover, S., "On Recognizing Children's Universal Rights: What needs to change in the Convention on the Rights of the Child", International Journal of Children's Rights 2004 (12(3)), 259-271.

Hitch, L., "Non-discrimination and the rights of the child. Article 2", New York University Law School Journal of Human Rights 1989 (7), 47-63.

Hodgkin, R. and Newell, P., The Implementation Handbook for the Convention on the Rights of the Child (New York: UNICEF, 2002).

Holmes, E., "Anti-discrimination Rights without Equality", Modern Law Review 2005 (68(2)), 175-194.

Kewenig, W., Der Grundsatz der Nichtdiskriminierung im Völkerrecht der internationalen Beziehungen, Vol. I: Der Begriff der Diskriminierung (Frankfurt: Athenäum, 1972).

Lansdown, G., Report on the lives of disabled children for the UN General Assembly Special Session on Children (New York, 2001), http://www.daa.org.uk/ItisOurWorldToo.htm

LeBlanc, L.J., The Convention on the Rights of the Child. United Nations Lawmaking on Human Rights (Lincoln: University of Nebraska Press, 1995).

Marks, S. and Clapham, A., "Children", in International Human Rights Lexicon (Oxford: Oxford University Press, 2005).

McGillivray, A., "Why Children Do Have Equal Rights (Reply to Laura Purdy)", International Journal of Children's Rights 1994 (1), 243-258.

McKean, W., Equality and Discrimination under International Law (Oxford: Oxford University Press, 1983).

Muscroft, S., Children's Rights: Equal Rights? Diversity, Difference and the Issue of Discrimination (London: The International Save the Children Alliance, 2000).

Partsch, K.J., "Discrimination", in The European System for the Protection of Human Rights (Boston: Martinus Nijhoff, 1993).

Ramcharan, B.G., "Equality and Non-Discrimination", in L. Henkin (ed.), The International Bill of Rights: The Covenant on Civil and Political Rights (New York: Columbia University Press, 1983).

Raz, J., The Morality of Freedom (Oxford: Clarendon, 1986).

Tomuschat, Chr., "Equality and Non-Discrimination under the International Covenant on Civil and Political Rights", in Staatsrecht, Völkerrecht, Europarecht : Festschrift für Hans-Jürgen Schlochauer zum 75. Geburtstag am 28. März 1981 (Berlin and New York: W. de Gruyter, 1981). 
Vierdag, E., The Concept of Discrimination in International Law, with Special Reference to Human Rights (The Hague: Martinus Nijhoff, 1973).

Westen P., "The empty idea of equality", Harvard Law Review 1982-3 (95), 537-596.

\section{Notes}

* PD (Bern), Dr.iur. (Fribourg), M.Jur. (Oxon.), lic.iur. (Fribourg and Vienna). This is a revised version of a presentation on 6th September, 2005 within the Masters in Advanced Studies on the Rights of the Child at the University of Fribourg. I would like to thank all participants for their comments and questions, and Pascal Pichonnaz for inviting me to lecture on this issue.

' See the other examples mentioned in Hodgkin/Newell, 2002, p. 28; Muscroft, 2000, pp. $32-40$.

${ }^{2}$ The present paper focuses mainly on the legal principle of non-discrimination and on the international legal principle of non-discrimination.

${ }^{3}$ ICJ, South West Africa, Second Phase, (1966) ICJ 3, 6.

${ }^{4}$ There are even more controversies as to the meaning of the principle in national law and $I$ will focus on international law in this article. See e.g. McKean, 1983, Introduction.

${ }^{5}$ Contra: Holmes, 2005.

- Human Rights Committee's General Comment 18 on Non-Discrimination, 10/11/1989, HRI/GEN/1/Rev. 5, reproduced in Compilation of General Comments and General Recommendations adopted by Human Rights Treaty Bodies, UN Doc. HRU/GEN/1 (1992).

${ }^{7}$ See ECHR, Belgian Linguistic Cases, Series A, No 6, 1986, par. 10. See also the Human Rights Committee's General Comment 18 on Non-Discrimination, 10/11/1989, HRI/GEN/1/Rev. 5, reproduced in Compilation of General Comments and General Recommendations adopted by Human Rights Treaty Bodies, UN Doc. HRI/GEN/1 (1992), par. 13.

${ }^{8}$ See PICJ, Minority Schools in Albania, Series A/B, No 64, 1935, p. 19. See also the Human Rights Committee's General Comment 18 on Non-Discrimination, 10/11/1989, HRI/GEN/1/Rev. 5, reproduced in Compilation of General Comments and General Recommendations adopted by Human Rights Treaty Bodies, UN Doc. HRI/GEN/1 (1992), par. 8.

${ }^{9}$ See e.g. ECJ, Case C-450/93, Kalanke v. Freie Hansestadt Bremen, ECR 1995 I-3051.

${ }^{10}$ See ECHR, Belgian Linguistic Cases, Series A, No 6, 1986, par. 10.

${ }^{11}$ See the Human Rights Committee's 18 on Non-Discrimination, 10/11/1989, HRI/GEN/1/Rev. 5, reproduced in Compilation of General Comments and General Recommendations adopted by Human Rights Treaty Bodies, UN Doc. HRI/GEN/1 (1992), par. 10. See also art. 1 par. 4 of the Racial Discrimination Convention, art. 4 par. 1 of the Women's Discrimination Convention and art. 27 of the International Covenant on Civil and Political Rights.

${ }^{12}$ See Judge Tanaka, South West Africa, Second Phase, (1966) ICJ 3, 293.

${ }^{13}$ See e.g. the 1960 UNESCO Convention against Discrimination in Education.

${ }^{14}$ See e.g. the 1979 UN Convention on the Elimination of All Forms of Discrimination of Women or the 1966 UN Convention on the Elimination of All Forms of Racial Discrimination.

${ }^{15}$ See also the Human Rights Committee's 18 on Non-Discrimination, 10/11/1989, HRI/GEN/1/Rev. 5, reproduced in Compilation of General Comments and General 
Recommendations adopted by Human Rights Treaty Bodies, UN Doc. HRI/GEN/1 (1992), par. 12.

${ }^{16}$ See ECHR Dudgeon v. United Kingdom. Series A, n. 45, 1981.

17 There are other less general ones, of course, such as the ILO Conventions, for instance. See Marks/Clapham, 2005, p. 27.

${ }^{18}$ See on recent efforts of integration of the (child and adult) gender perspective, Hodgkin/Newell, 2002, p. 34.

${ }^{19}$ See ECHR, Loizidou v. Turkey, [1998] ECHR 60 (28 July 1998).

${ }^{20}$ Committee on the Rights of the Child, General Comment 1, 2001, HRI/GEN/1/Rev. 5, p. 257.

${ }^{21}$ Committee on the Rights of the Child, Guidelines for Periodic Reports, 1993i: 4. 


$$
\text { . }
$$

